\title{
Malaysian Public Sector Ethical Stimulants
}

\author{
Azizah Abdullah $^{1}$, Norazamina Mohamed ${ }^{1}$, Najihah Marha Yaacob ${ }^{1} \&$ Suraya Ahmad ${ }^{1}$ \\ ${ }^{1}$ Faculty of Accountancy, Universiti Teknologi Mara, Malaysia \\ Correspondence: Azizah Abdullah, Faculty of Accountancy, Universiti Teknologi Mara, Malaysia. E-mail: \\ aziza588@uitm.edu.my
}

Received: March 16, 2020

Accepted: April 30, 2020

Online Published: June 29, 2020

doi:10.5430/ijfr.v11n3p100

URL: https://doi.org/10.5430/ijfr.v11n3p100

\begin{abstract}
Public becomes inquisitive about the role of public sector in mitigating fraud, corruption and corporate misconduct. Downe, Cowell, \& Morgan, (2016) suggest that public sector agencies with highly ethical leaders and proper guidelines not only be able to prevent unethical behaviour but also improve its productivity and services performances. This research is conducted with the objective to identify ethical stimulants in Malaysian public sector agencies. In addition, it aims to determine the five ethical stimulants. Agency members' viewpoints were obtained using quantitative survey-based questionnaires. Exploratory factor analysis suggests five ethical stimulants which include ethical leadership, ethical employees, spiritual encouragement, spirituality acceptance, and ethical guidelines.
\end{abstract}

Keywords: ethical leadership, ethical employees, spiritual encouragement, spirituality acceptance, ethical guidelines

\section{Introduction}

Malaysia has shown its commitment to combat corruption in response to some report highlighting its government inefficient bureaucracy, corruption and lowly work ethics amongst its workforce. National Integrity Plan was launched in 2004 focusing on moral and spiritual values. Despite this, over the years, media highlights corporate and financial scandals, such as Bumiputra Malaysia Finance, Sime Darby, PERWAJA Steel Bhd, Transmile, LFE Corporation Bhd., Linear Corporation Bhd., Kenmark Industrial and PKFZ (Ismail, 2013), 1MDAB Corporation and Tabung Haji. All these incidences have received considerable attention from the public and the media (The Star on Line, May 10, 2015; The Straits Times, March 10, 2015). According to Sims (2002) in many cases, the wrongdoing of personnel in any organization has been found to be due to the absence of ethical self-identity. This study intends to identify ethical stimulants in Malaysia public agencies from the perspectives of internal stakeholders' directive.

\section{Literature Review}

Previous research (Cherrington and Cherrington (1985), Chappell and Di Martino (2000), Weaver, Treviño, \& Cochran (1999), Vardi \& Weitz (2004)) examine various factors related to ethics including theft in the workplace, violent behaviour at work, ethical quality within small sample. The current study probes into internal stakeholders' directive measured using ethical leadership, ethical employee, spirituality encouragement, spirituality acceptance, and ethical guidelines.

Literature indicates the spotlight is on effective leadership rather than ethical leadership. Ciulla (1998) stated, "it is remarkable that there has been little in the way of sustained and systematic treatment of the subject [ethical leadership] by scholars". Few available definitions for ethical leadership include by Lord and Maher (1991) and Brown, Treviño, \& Harrison (2005) which emphasise the persona of a leader.

Corporate scandals (Enron, WorldCom) raised the issue of ethicality among corporate leaders and political leaders. As a result, practitioners and researchers are increasingly interested in ethical leadership. (Brown \& Treviño, 2006; Brown et. al, 2005) argued that ethical leadership positively affects organizational performance while helping develop the forces that shape employees' moral decision-making. Recent research (Norazamina, Azizah, Najihah \& Suraya, 2018) explored the leadership moral characteristics and the guidelines within the Malaysian public sector.

Treviño et al. (2003) propose that leadership persona should complemented with good reward system and interaction. Shamas-ur-Rehman, Toor \& Ofori (2009) highlighted leaders with good ethics would be able to transform employees' attitudes and organizational culture positively. Kalshoven, Den Hartog \& De Hoogh (2012) highlights 
the substance of having multi measures of ethical leaders which supports previous research. While Riggio, Zhu, Reina \& Maroosis (2010) proposed a virtue-based ethics approach for understanding ethical leadership.

Many studies in the past discuss about ethical leadership measurements (Kalshoven et al. (2012), Mayer et al. (2012) De Hoogh \& Den Dartog (2008) Hanges \& Dickson, 2004; House \& Aditya, 1997, Detert, Treviño, Burris, \& Andiappan, 2007). The current study, ethical leadership is measured based on three different scales which adapted from leadership role model and Kaptein et al. 2005. The unethical acts of employees can also lead to the scandals and outrage that can destroy careers and even organizations. Ethical employees are those who voluntarily support the organization values (Robinson \& Bennett, 1995 Massi-Lindsey, Yun and Hill, 2007). Lacks ethics among the personnel leads to the wrongdoing. Ethical audit should be encouraged (Deloitte \& Touche, 2002). The Herald (2013) highlights the ethical elements of ethical employees as integrity, valuing diversity, cooperative, accountability, teamwork and commitment. Other research (Ajzen \& Fishbein (1980), Trevino (1992) Abdullah, Sulong \& Said (2014)) attempts to link theory of reasoned action to the employees' behaviour.

Roozen, Pelsmacker, and Bostyn (2001), public-sector employees are expected to be more concerned about ethical aspects than those in the private sector. This might be due to the high degree of respect and trust from the public. Trevino, Hartman and Brown (2000) believe that an ethical employee is a substantive basis to become an ethical leader. Even the mass media has highlighted concern about the need for ethical employees. Thus, an organizational ethical self-identity precautionary model that identifies ethical employees would assist the government agencies in introducing precautionary measures, as well as in terms of the monitoring and surveillance aspects of their management. Indeed, it would help prevent mismanagement or misconduct and, in turn, gain public trust.

Multiple stances on workplace spirituality. Generally, spirituality can be categorised into religious and non-religious. Some (Koenig, McCullough, \& Larson (2001), Baggini (2008)) argue that spirituality is a personal quest includes unobservable emotional feelings or behaviour which then leads to motivation. Thompson (2000) suggested that workplace spirituality is an encouraging factor which supplements the understanding and identification of the inner and inward life of the employees. This encourages self-enforcement ethical values. Spirituality combines with transactional actions and transformational leadership would enhance the organisation's performance (Afsar, Badir and Kiani, (2016), Pawar (2016), Djafri et al. (2017))

Spirituality acceptance as measured by the measurement used in study's Afsar et al. (2016). In this view, spirituality acceptance is the acceptance of individual/organization in promoting employees' experience of transcendence and togetherness with other colleagues' meaning of life. Organization differs in terms of activities, cultures and value. Consequently the ethical values and risk also differ. Previous research (Paine (2003), Treviño \& Nelson (1995)) suggest that employees be aware of the organizational settings could discourage misconducts. This can be ensured through establishment of code of conduct (Kaptein et al. (2005))

In conclusion, code of conduct which is a normative influence framework couple with ethical leaders, positive organisational values, personal needs at higher level of Maslow's Hierarchy, and good enforcement would inspire the employees to work ethically (Trevino \& Youngblood (1990), Ashkanasy et al. (2000), Roozen et al. (2001), (Elango, Pau, Kundu \& Paudel, 2010), Lu \& Lin (2014))

\section{Methodology}

Data for this study was collected using a questionnaire survey. The objective of the survey is to obtain responses from key informers from five categories of the public sector: statutory bodies, state departments, federal departments, district and land offices, and the local authorities which enable generalization of the appropriateness reflective measures of ethical self-identity in the public sector. The population of this study consists of 203 government agencies/departments. The final sample of 141 was selected at based on stratified random sampling; as shown in Table 1.

Table 1. Sample distribution

\begin{tabular}{lll}
\hline & Population & Sample \\
\hline Statutory Body & 33 & 23 \\
State Department & 49 & 34 \\
Federation Department & 62 & 43 \\
District and Land Office & 29 & 21 \\
Local Authority & 30 & 20 \\
\hline
\end{tabular}


Self-administered questionnaires were distributed in person to three (3) key informers from each government agency with the assistance of three trained enumerators. The key informers were from executive level and above. Finally, from the total of 423 questionnaires distributed (141 agencies x 3 government servants), 400 questionnaires were received, representing an overall response rate of $95 \%$. After data cleaning process 395 data were useful for statistical analysis using SPSS software version 21.0. The reliability analysis was conducted to measure the stability and consistency of the instruments. In addition, factor loading analysis was run to reduce the large number of variables to a smaller set of underlying factors; thus, the essential information in the variables could be summarized.

\section{Results and Discussion}

The Cronbach's alpha under reliability test for each construct exceeds 0.60 , which indicates that the measurement scale of the all constructs have internal consistency. The test shows that some items for each construct need to be deleted, which increases the Cronbach's alpha; as shown in Table 2. This indicates that factors chosen are reliable.

Table 2. Reliability Test

\begin{tabular}{llllll}
\hline & EL & EE & SE & SA & EG \\
\hline Original Items & 21 & 17 & 8 & 7 & 28 \\
\hline Before Delete CAlpha & 0.970 & 0.967 & 0.913 & 0.942 & 0.978 \\
\hline Items Deleted & 2 & 1 & 1 & 1 & 0 \\
\hline New Items & 19 & 16 & 7 & 6 & 28 \\
\hline After delete item CA & 0.978 & 0.969 & 0.917 & 0.956 & - \\
\hline
\end{tabular}

Note: EL= Ethical Leadership, EE= Ethical Employees SE= Spiritual Encouragement, SA= Spirituality Acceptance, $\mathrm{EG}=$ Ethical Guidelines.

To construct a reliable test, factor analysis is an additional means of determining whether items are tapping into the same construct. There are seven methods of factor extraction, which this study chooses PAF (Principle Axis Factoring).

In Exploratory Factor Analysis, an examination of the correlation matrix indicates that a considerable number or correlations exceed 0.3 , so the matrix is suitable for factoring. Table 3 shows the results of the KMO and Bartlett's Test and total variance explained before and after further deletion of items. It displays Bartlett's Test of Sphericity is significant at 0.00 (less than 0.05 ) and the KMO is greater than 0.60. The significant result indicates that the correlation matrix is significantly different from an identity matrix, in which correlations between variables are all zero. Anti-image correlation matrix reveals that all our measures of sampling adequacy are well above the acceptable level of 0.5. The total variance explained for each attribute of ethical self-identity had increased after further deletion of items were made except for ethical leadership and spirituality acceptance which remain the same because no further deletion of items were made.

Table 3. KMO and Bartlett's Test and total variance explained

\begin{tabular}{llllll}
\hline & EL & EE & SE & SA & EG \\
\hline New Items & 19 & 16 & 7 & 6 & 28 \\
\hline KMO & 0.965 & 0.952 & 0.900 & 0.896 & 0.959 \\
\hline Bartlett's Test & 0.000 & 0.000 & 0.000 & 0.000 & 0.000 \\
\hline Total variance explained & $69.56 \%$ & $74.24 \%$ & $63.57 \%$ & $78.62 \%$ & $69.89 \%$ \\
\hline Items deleted & - & 2 & 1 & - & 9 \\
\hline KMO & 0.965 & 0.946 & 0.901 & 0.896 & 0.946 \\
\hline Bartlett's Test & 0.000 & 0.00 & 0.000 & 0.000 & 0.000 \\
\hline Total variance explained & $69.56 \%$ & $76.67 \%$ & $68.63 \%$ & $78.62 \%$ & $75.54 \%$ \\
\hline Final items & & 14 & 6 & 5 & 19 \\
\hline Factoring & 1 factor & 2 factors & 1 factor & 1 factor & 3 factors \\
\hline
\end{tabular}


In addition, the principal axis for factor analysis with varimax rotation was conducted to assess the underlying 19 reflective measures of ethical leadership, 16 reflective measures of ethical employees, 7 reflective measures of spiritual encouragement, 6 reflective measures of spirituality acceptance and 28 reflective measures of ethical guidelines (internal stakeholders' directive), all assumptions for independent sampling were met. The extraction results in one (1) factor of ethical leadership with $69.56 \%$ of the variance, in two (2) factors of ethical employees with $74.24 \%$ of the variance, in one (1) factor of spiritual encouragement with $63.57 \%$ of the variance, in one (1) factor spiritual acceptance with $78.62 \%$ of the variance, and in three (3) factors of ethical guidelines with $69.89 \%$ of the variance. From the 16 items of ethical employees, the rotated factor matrix determined that two (2) need to be deleted, leaving 14 items. From the 7 items of spiritual encouragement, the rotated factor matrix determined that one (1) needs to be deleted, leaving 6 items. From the 28 items of ethical guidelines, the rotated factor matrix determined that nine (9) need to be deleted, leaving 19 items.

\section{Conclusion}

Corruption is a global phenomenon affecting almost every part of the world and often considered as the most talked issue in the world. Ethical self-identity is introduced as an effective tool to prevent or at least mitigate the fraud and corruption rate. The main objective of this study is to measure the reliability of items in five attributes of ethical self-identity and to summarize them into a set of factors. The suitable measurement of ethical self-identity in Malaysian public sector is explored which includes five determinants with confirmed reflective measures (RM: ethical leadership (19 RM) ethical employees (14 RM), spiritual encouragement (6 RM), spirituality acceptance (6 RM), and ethical guidelines (19 RM).

The results of this study may assist the government agencies and departments to instil all five stimulants of ethical self-identity in Malaysian public agencies and in other public sector with similar setting in Malaysia. Furthermore, the reflective measures for each determinant can be applied to assess the ethical self-identity of the organization. It is hoped, this study will provide clear ethical direction to public officials in ensuring the survival of the Malaysian Public Sector.

\section{Acknowledgements}

The authors gratefully acknowledge the research grant-Fundamental Research Grant Scheme [600-RMI/FRGS 5/3 (89/2015)] financed by the Ministry of Higher Education and Universiti Teknologi MARA.

\section{References}

Abdullah, A., Sulong, Z., \& Said, M. S. (2014). An analysis on ethical climate and ethical judgment among public sector employees in Malaysia. Journal of Applied Business and Economics, 16(2), 133-142.

Afsar, B., Badir, Y., \& Safdar Kiani, U. (2016). Linking spiritual leadership and employee pro-environmental behavior: The influence of workplace spirituality, intrinsic motivation, and environmental passion. Journal of Environmental Psychology, 45, 79-88.

Ajzen, I., \& Fishbein, M. (1980). Understanding attitudes and predicting social behavior. Englewood Cliffs, NJ: Prentice-Hall.

Ashkanasy, N., Falkus, S., \& Callan, V. (2000). Predictors of ethical code use and ethical tolerance in the public sector. Journal of Business Ethics, 25, 237-253.

Baggini, J. (2008). The lost rewards of the spiritual life. Free Inquiry, 28(4), 41-43.

Bandura, A. (1986). Social foundations of thought and action: A social cognitive theory. Englewood Cliffs, NJ: Prentice- Hall, Inc.

Benefiel, M., Fry, L., \& Geigle, D. (2014). Spirituality and religion in the workplace: history, theory, and research. Psychol Relig Spiritual 6(4), 175-187.

Brown, M. E., \& Trevino, L. K. (2006). Ethical leadership: A review and future directions. The Leadership Quarterly, 17(6), 595-616.

Brown, M. E., Trevino, L. K., \& Harrison, D. A. (2005). Ethical leadership: A social learning perspective for construct development and testing. Organizational Behavior and Human Decision Processes, 97(2), 117-134.

Cash, K. C., \& Gray, G. R. (2000). A framework for accommodating religion and spirituality in the workplace. The Academy of Management Executive, 14(3), 124-133.

Chappell, D., \& Di Martino, V. (1998, 2000). Violence at Work. ILO, Geneva. 
Cherrington, D. J., \& Cherrington, J. O. (1985). The Climate of Honesty in Retail Stores. In Terris W. (Ed.), Employee Theft: Research, Theory, and Applications. Park Ridge, Illinois: London House Press.

Ciulla, J. (1998). Ethics, the heart of leadership. Westport, CT: Quorum Books.

Clinard, M. B., \& Peter, C. Y. (2006). Corporate Crime (Reissue edition). New Brunswick, NJ: Transaction Publishers.

De Hoogh, A. H. B., \& Den Dartog, D. N. (2008). Ethical and Despotic Leadership, Relationships with Leader's Social Responsibility, Top Management Team Effectiveness and Subordinates' Optimism: A Multi-Method Study. The Leadership Quarterly, 19, 297-311.

Deloitte, \& Touche. (2002). Integrity \& Quality. New York: Deloitte \& Touche LLP.

Detert, J. R., Treviño, L. K., Burris, E. R., \& Andiappan, M. (2007). Managerial modes of influence and counter productivity in organizations: A longitudinal business-unit-level investigation. Journal of Applied Psychology, 94, 993-1005.

Elango, B., Paul, K., Kundu, S., \& Paudel, S. (2010). Organizational ethics, individual ethics, and ethical intentions in international decision-making. Journal of Business Ethics, 97(4), 543-56.

Fares Djafri, \& Kamaruzaman Noordin. (2017). The impact of workplace spirituality on organizational commitment: A case study of Takaful agents in Malaysia. Humanomics, 33(3), 384-396, https://doi.org/10.1108/H-02-2017-0018

Fry, L. W. (2003). Toward a theory of spiritual leadership. The Leadership Quarterly, 14(6), 693-727.

Ghiselli, E. E., Campbell, J. P., \& Zedeck, S. (1981). Measurement theory for the behavioral sciences. San Francisco: W.J. Freeman.

Gorsira, M., Steg, L., Denkers, A., \& Huisman, W. (2018). Corruption in Organizations: Ethical Climate and Individual Motives. Administrative Sciences, https://doi.org/10.3390/admsci8010004

Hanges, P. J., \& Dickson, M. W. (2004). The development and validation of the Globe culture and leadership scales. In R. J. House, P. J. Hanges, M. Javidan, P. W. Dorfman, \& V. Gupta (Eds.), Culture, leadership, and organizations: The GLOBE study of 62 societies (Vol. 1). Thousand Oaks, CA: Sage.

Hinkin, T. R. (1998). A brief tutorial on the development of measures for use in questionnaires. Organizational Research Methods, 1, 104-121.

House, R. J., \& Aditya, R. N. (1997). The social scientific study of leadership: Quo vadis?. Journal of Management, 23, 409-473.

Ismail, A. M. (2013). Development of A Corporate Integrity Assessment Instrument Using Corporate Governanec Indicators in Malaysia Doctor of Philosophy, Victoria University.

Javed, B., Naqvi, S. M. M. R., Khan, A. K., Arjoon, S., \& Tayyeb, H. H. (2017). Impact of inclusive leadership on innovative work behavior: The role of psychological safety. Journal of Management \& Organization, 1-20.

Kalshoven, K., Den Hartog, D. N., \& De Hoogh, A. H. (2012). Ethical leadership and follower helping and courtesy: Moral awareness and empathic concern as moderators. Applied Psychology. https://doi.org/10.1111/j.1464-0597.2011.00483.x

Kaptein, M., Huberts, L., Avelino, S., \& Lasthuizen, K. (2005). Demonstrating ethical leadership by measuring

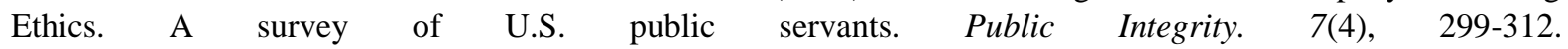
https://doi.org/10.1080/10999922.2005.11051286

Koenig, H. G., McCullough, M. E., \& Larson, D. B. (2001). Handbook of religion and health. New York: Oxford Press.

Lord, R., \& Maher, K. (1991). Leadership and information processing: Linking perception and performance. Boston, MA: Unwin Hyman.

Lu, C. S., \& Lin, C. C. (2014). The effect of ethical leadership and ethical climate on employee ethical behavior in the international port context. Journal of Business Ethics, 124, 209-223.

Massi-Lindsey, L. L., Yun, K. A., \& Hill, J. B. (2007). Anticipated guilt as motivation to help unknown others: An examination of empathy as a moderator. Communication Research, 34, 468-490. https://doi.org/10.1177/0093650207302789 
Mayer, D. M., Aquino, K., Greenbaum, R. L., \& Kuenzi, M. (2012). Who Displays Ethical Leadership, and Why does it matter? An Examination of Antecedents and Consequences Of Ethical Leadership. Academy Of Management Journal, 55(1), 151-171. https://doi.org/10.5465/amj.2008.0276

Paine, K. D. (2003). Guidelines for measuring trust in organizations. Retrieved from http://www.instituteforpr.org/wp-content/uploads/2003_MeasuringTrust.pdf

Riggio, R. E., Zhu, W., Reina, C., \& Maroosis, J. A. (2010, January). Virtue-Based Measurement of Ethical Leadership: The Leadership Virtues Questionnaire. Consulting Psychology Journal, 62(4), 235-250.

Robinson, S. L., \& Bennett, R. (1995). A typology of deviant behaviors: A multidimensional scaling study. Academy of Management Journal, 38, 555-572.

Roozen, I., Pelsmacker, P. D., \& Bostyn, F. (2001). The Ethical Dimensions of Decision Processes of Employees. Journal of Business Ethics, 33(2), 87-99.

Rosli, M. H., Aziz, M. A. bin A., Mohd, F., \& Said, J. (2015, April). Integrity Systems in Malaysian Public Sector: An Empirical Finding. Procedia Economics and Finance, 28, 260-265. http://doi.org/10.1016/S2212-5671(15)01109-0

Sadiq, M. Y., \& Abdullahi, M. (2013). Corruption as the bane of Nigeria's Development: Causes and remedies. International Journal of Economic Development Research and Investment, 4(1), 83-93.

Shamas-ur-Rehman, T., \& Ofori, G. (2009). Ethical Leadership: Examining the relationships with Full Range Leadership Model, Employee Outcomes, and Organizational Culture. Journal of Business Ethics, 90, 533-547.

Sims, R. L. (2002). Ethical rule breaking by employees: a test of social bonding theory. Journal of Business Ethics, 40(2), 101-9.

The Herald. (2013). Attributes of an ethical employee. Retrieved from https://www.herald.co.zw/attributes-of-an-ethical-employee

Thompson, W. D. (2000). Can you train people to be spiritual?. Training and Development, 54(12), 18-19.

Tombaugh, J. R., Mayfield, C., \& Durand, R. (2011). Spiritual expression at work: exploring the active voice of workplace spirituality. International Journal of Organizational Analysis, 19(2), 146-170.

Treviño, L. K., Brown, M., \& Hartman, L. P. (2003). A qualitative investigation of perceived executive ethical leadership: Perceptions from inside and outside the executive suite. Human Relations, 55, 5-37.

Treviño, L. K., Hartman, L. P., \& Brown, M. E. (2000). Moral person and moral manager: How executives develop a reputation for ethical leadership. California Management Review, 42, 128-142.

Trevino, L., \& Brown, M. (2004). Managing to be ethical: Debunking five business ethics myths. Academy of Management Executive, 18(2), 69-83.

Tu, Y., \& Lu, X. (2016). Do ethical leaders give followers the confidence to go the extra mile? The moderating role of intrinsic motivation. Journal of Business Ethics, 135(1), 129-144.

Vardi Y., \& Weitz E. (2004) Misbehavior in Organizations: Theory, Research and Management. Mahwah, NJ: Lawrence Erlbaum.

Weaver, G., L. Trevin, O., \& Cochran, P. (1999). Integrated and Decoupled Corporate Social Performance: Manager Commitments, External Pressures, and Corporate Ethics Practices. Academy of Management Journal, 42, 539-52. 